\title{
The Roman Monster
}

An Icon of the Papal Antichrist In Reformation Polemics

Lawrence P. Buck

$\$ 49.95$ pb 9781612481067

$\$ 39.99$ ebook 9781612481074

Early Modern Studies 13 • 272 pp.

13 illus., biblio., index $\bullet$ 6x9"

This book is a fascinating and meticulous study of antipapal polemics. Lawrence Buck skillfully analyzes the iconography of the various images of a grotesque monstrosity that had been discovered after the Tiber River flooded Rome. . . . This intriguing book should attract widespread interest from Reformation scholars. It is one of the freshest and most original books to have appeared in several years. -Jonathan Zophy

Of all the curious, horrifying cast of monstrous characters known to early-modern Europeans, the Papal Ass was certainly one of the strangest. . . . Lawrence Buck's dogged attempts to cast light upon the trail that knowledge and exploitation of this event followed reveals a great deal about the ways in which religious, scientific, and preternatural knowledge got around in pre-modern society.

\section{ANY BOOK • ANY TIME • 15\% DISCOUNT \& FREE SHIPPING • tsup.truman.edu}




\section{Ev \\ Early Modern Women An Interdisciplinary Journal}

\section{CELJ \\ Winner of the 2013 Council of Editors of Learned Journals Voyager Award}

for excellence in journals covering the period $1500-1800$

$E M W J$ invites submissions of articles on the topic of women and gender in the early modern period, $1400-1750$. The Journal awards an annual prize of $\$ 1000$ for the best article.

We are pleased to inform our readers that effective 2014, and with volume 9, EMWJ will be published biannually. The Forum for volume 10.1 (2015) will be dedicated to women and work in recognition of the pioneering scholarship of Alice Clark (1874-1934) whose Working Life of Women in the Seventeenth Century appeared in 1919. Clark, whom we would now call an independent scholar, worked in the family factory of C. and J. Clark, Ltd., the famous British manufacturer of shoes, and became a director in 1904 .

Topics to be considered will include women as entrepreneurs, merchants, "capitalists," and women of business broadly conceived. Proposals for other topics that fit within the general category of the "working life of women" are also welcome. Contributions should be between 3000-3500 words.

Please contact the editors at emwj@miami.edu if you are interested in proposing a topic.

Editors:

Anne J. Cruz, Professor of Spanish

Mary Lindemann, Professor of History

Mihoko Suzuki, Professor of English

Center for the Humanities

University of Miami

Coral Gables FL 33124

http://humanities.miami.edu/publications/emwj

To subscribe to the journal, send an email to: emwjournal@asu.edu

\section{Early Modern Women} AN INTERDISCIPLANAK fOURNA
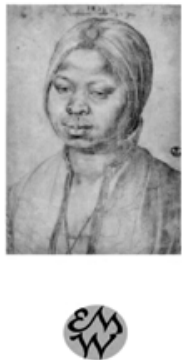

Fall 2013, Volume 8

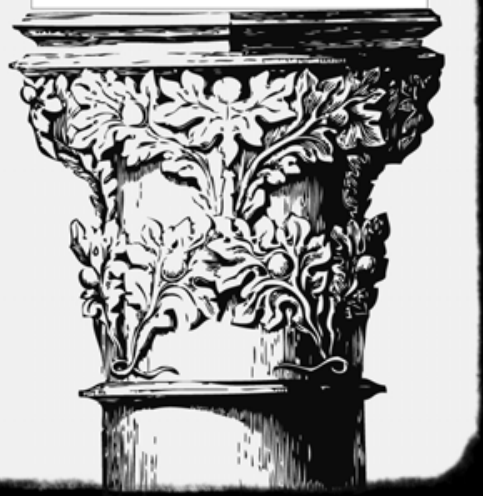

